Published in final edited form as:

Vascul Pharmacol. 2007 May ; 46(5): 367-372.

\title{
Inhibition of the $\alpha_{10}$-Adrenergic Receptor Gene by RNA interference (RNAi) in Rat Vascular Smooth Muscle Cells and its effects on other adrenergic receptors
}

\author{
Bei Sun, Ekaterina Kintsurashvili, Deborah Ona, Ivana Ignjacev-Lazich, Irene Gavras, and \\ Haralambos Gavras \\ Hypertension and Atherosclerosis Section of the Department of Medicine, Boston University School \\ of Medicine, Boston, MA
}

\begin{abstract}
Sympathetic-induced vasoconstriction is mediated by various adrenergic receptor (AR) subtypes located on membranes of vascular smooth muscle cells (VSMC) located on the arterial wall, but is mostly attributed to activation of the $\alpha_{1 D^{-}} \mathrm{AR}$. In order to study interaction and crosstalk among AR genes, we induced post-transcriptional silencing of the $\alpha_{1 D^{-A R}}$ gene in cultured VSMC using the RNAi technique. A pSEC neo expression plasmid vector containing a small interfering RNA (siRNA) sequence selected to bind to the targeted mRNA of the $\alpha_{1 \mathrm{D}}$-AR gene was transfected into cultured VSMC from rat aorta. The RNA expression of all AR-subtype genes was assessed by Q-RT-PCR and the $\alpha_{1 \mathrm{D}}$ and $\alpha_{2 \mathrm{~A}}$-AR proteins quantified by Western blot. In siRNA transfected cells, the $\alpha_{1 \mathrm{D}^{-}}$ AR protein levels decreased by $55 \%, 69 \%$ and $75 \%$ at $24 \mathrm{~h}, 48 \mathrm{~h}$ and $72 \mathrm{~h}$, respectively $(\mathrm{p}<0.03-$ 0.01 ) with progressive increases in its gene expression by $50 \%-61 \%$ and concurrent increase in $\alpha_{2 \mathrm{~A}}$-AR protein peaking at $48 \mathrm{~h}$. Decreases were noted in expression of the $\alpha_{1 \mathrm{~A}}, \alpha_{2 \mathrm{~A}}$, and $\beta_{3} \mathrm{AR}$ genes. We conclude that post-transcriptional silencing of the $\alpha_{1 D^{-}}$AR gene leads to significant decrease in receptor protein despite reactive increase in gene expression. However, suppression of one AR leads to reactive changes in other subtypes, indicating that cross-talk among related genes, whose products have overlapping functions, may partly offset anticipated effects in vivo.
\end{abstract}

\section{Introduction}

The sympathoadrenal system exerts its effects via three major types of adrenergic receptors (AR): $\alpha_{1}, \alpha_{2}$ and $\beta$; for each one of these, three subtypes have been identified and cloned: $\alpha_{1 \mathrm{~A}}, \alpha_{1 \mathrm{~B}}, \alpha_{1 \mathrm{D}}, \alpha_{2 \mathrm{~A}}, \alpha_{2 \mathrm{~B}}, \alpha_{2 \mathrm{C}}$ and $\beta_{1} \beta_{2}, \beta_{3}$. All are members of the guanidine nucleotide (G) regulatory protein-coupled receptor superfamily (Bylund, 1992; Lefkowitz and Caron, 1988). All are activated to variable extent by catecholamines or other sympathomimetic agents, which elicit type-specific and tissue specific responses. In the past we have been particularly interested in the role of various $\alpha_{2}$-AR subtypes in hypertension and heart failure (Gavras et al., 2001). In those studies we employed either gene knockout mice with deleted gene for a specific $\alpha_{2}-$ AR subtype (Makaritsis et al., 2000) or gene treatment in rats using antisense technology to inhibit a specific subtype's gene (Kintsurashvili et al., 2001; Kintsurashvili et al., 2003).

Please send correspondence to: Haralambos Gavras, M.D., Chief, Hypertension \& Atherosclerosis Section, Boston University School of Medicine, 715 Albany Street, Boston, MA 02118, Tel.: (617) 638-4025, Fax: (617) 638-4027, E-mail: hgavras@ bu.edu.

Publisher's Disclaimer: This is a PDF file of an unedited manuscript that has been accepted for publication. As a service to our customers we are providing this early version of the manuscript. The manuscript will undergo copyediting, typesetting, and review of the resulting proof before it is published in its final citable form. Please note that during the production process errors may be discovered which could affect the content, and all legal disclaimers that apply to the journal pertain. 
Activation of postjunctional $\alpha_{1}$-ARs contributes to a number of sympathoadrenal actions relevant to hypertension (Gavras et al., 1995) including renal sodium handling (Jeffries et al., 1988), cardiac rhythm (Kurz et al., 1991), contractility (Endoh et al., 1991) and hypertrophy (Ikeda et al., 1991), as well as vascular smooth muscle cell (VSMC) contraction, resulting in systemic vasoconstriction (Ruffolo et al., 1991; Young et al., 1988). Indeed, stimulation of $\alpha_{1}$-ARs accounts for about $70 \%$ of the vasopressor response to catecholamines, whereas the post-synaptic $\alpha_{2}$-ARs account for the remainder 30\% (Duka et al., 2000). Ample evidence suggests that the $\alpha_{1}$-AR subtype mostly responsible for vascular contractile responses in big arteries (aorta, femoral and iliac) is the $\alpha_{1 \mathrm{D}}-\mathrm{AR}$ (Gisbert et al., 2000; Hrometz et al., 1999; Piascik et al., 1995; Villalobos-Molina and Ibarra, 1999).

The current experiments were designed to further explore the function of the $\alpha_{1 D^{-}}$AR located in VSMC and its interaction with other ARs. Our hypothesis was that silencing of this AR's gene would elicit compensatory changes in expression of related AR subtypes. To this aim, we employed the RNAi technology (McManus and Sharp, 2002) that involves posttranscriptional gene silencing by use of short RNA nucleotide sequences complementary to selected 19-21 base regions of the target mRNA. The small interfering RNA (siRNA) sequence binds to the targeted mRNA, thus inducing its cleavage, degradation and ultimately loss of the encoded protein (Elbashir et al., 2001; Gitlin et al., 2002). By adapting this technology to the $\alpha_{1 D^{-}}$AR gene, we achieved the post-transcriptional inhibition of this gene in cultured VSMC and assessed $\alpha_{1 \mathrm{D}}-\mathrm{AR}$ protein production, as well as the effects on the possible cross-talk with other related AR subtype genes.

\section{Material and Methods}

\section{1. siRNA Constructs}

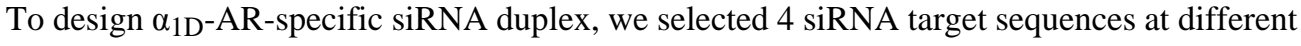
positions through the $\alpha_{1 D^{-}}$AR gene according to the Guidelines for siRNA target selection using Ambion's online target finder tool. Three of these are located in the ORF part and one in the 3'UTR. The sequences are 5'-GCTCAAGTACCCAGCCATTAT-3', 5GCCAAAGGATATCCCGGAACA-3', 5-GCTGTCATCTGCCAGGCTTAT-3' and 5'AAACTACTTAGTCAACTCCTA-3'. The selected sequences were submitted to a BLAST search against the rat genome to ensure specificity of targeted sequences. Sense and antisense templates were synthesized (Invitrogen, Carlsbad, CA), and then generated the precursor short hairpin RNA with mouse U6 RNA polymerase using the Silencer Express Cassette (Ambion, Austin, TX), which was cloned into pSEC neo expression vector to produce siRNA by in vitro transcription. A GAPDH siRNA expression plasmid was also constructed by pSEC neo vector as a positive control. Block-it U6 RNAi entry vector, which also expresses short hairpin RNA, was used to construct the $\alpha_{1 D^{-}} \mathrm{AR} / \mathrm{siRNA}$ plasmids containing these 4 different target sequences and to compare the knock-down efficiency.

\subsection{Cells and Transfection}

VSMC were isolated from the rat thoracic aorta of 8-week-old male Wistar rats by an explant method (Ross R, 1971) and were stained with smooth muscle-specific alpha-actin, indicating a smooth muscle phenotype. Cells were cultured in Dulbecco's modified Eagle's medium (DMEM Glucose $4.5 \mathrm{mg} / \mathrm{ml}$ ) supplemented with $10 \%$ fetal bovine serum, penicillin (100U/ $\mathrm{ml}$ ), and streptomycin $(100 \mu \mathrm{g} / \mathrm{ml})$ in humidified atmosphere at $37^{\circ} \mathrm{C}$ with $5 \%$ carbon dioxide. The cells were trypsinized every 5 to 7 days. All experiments were performed on cells between passage 6 to 10 .

One day before transfection, cells were trypsinized and resuspended in a new medium without antibiotics, and transferred onto a $100 \mathrm{~mm}$ dish at a density of $5 \times 10^{6}$ cells per dish. The 
transfection was performed using Lipofectamine 2000, and the whole procedure and conditions were according to the manufacturer's protocol. (Invitrogen). Each tranfection was performed on three groups under the same conditions; an $\alpha_{1 \mathrm{D}}-\mathrm{AR} / \mathrm{pSEC}$ transfection group, a GAPDH/ pSEC transfection group and a control non-transfection group. Twenty-four, 48 and 72 hours after transfection, all cells from the three groups were harvested for RT-PCR and Western blot analysis to investigate the level of RNA and endogenous protein.

\subsection{Total RNA Isolation}

Total RNA was prepared from siRNA-transfected rat VSMC cells or non-transfected cells using the TRIzol Reagents (GIBCO-BRL; Gaithersburg, MD) according to the manufacturer's instructions. This was followed by DNase treatment and removal of contaminating DNA from the RNA preparation with DNA-free (Ambion, Austin, TX).

\subsection{Analysis of adrenergic receptor mRNA levels by RT-PCR}

The RNA expression of $\alpha_{1 \mathrm{D}}$-AR gene as well as $\alpha_{1 \mathrm{~A}}, \alpha_{1 \beta}$ and $\alpha_{2 \mathrm{~A}}, \alpha_{2 \mathrm{~B}}, \alpha_{2 \mathrm{C}}, \beta_{1}, \beta_{2}, \beta_{3}$-AR genes in rat VSMC was examined by quantitative reverse transcriptase-polymerase chain reaction (RT-PCR) techniques. From each sample, $1 \mu \mathrm{g}$ of total RNA was converted to cDNA using a RNA PCR kit (Perkins-Elmer; Branchburg, NJ), and PCR was performed with oligonucleotide primers complementary to each rat AR subtype cDNA. The primers of each AR subtype and the length of PCR product fragments are shown in Table 1. The reverse transcription was performed by first incubating at room temperature for 10 minutes and then at $42^{\circ} \mathrm{C}$ for 15 minutes followed by heating at $95^{\circ} \mathrm{C}$ for 5 minutes. To establish conditions that allow comparison of the amounts of cDNA produced by RT-PCR, we varied the number of cycles from 24 to 40; a cycle number of 30 was chosen to compare the different levels of expression of various mRNAs. Three-step cycling was performed as follows: denaturation for $45 \mathrm{~s}$ at $95^{\circ} \mathrm{C}$, annealing for $45 \mathrm{~s}$ at $60^{\circ} \mathrm{C}$ and extension for 1 minute at $72^{\circ} \mathrm{C}$. The 3 -step cycle was repeated for 35 cycles and followed by a final extension at $72^{\circ} \mathrm{C}$ for 5 minutes. Each of the PCR products was separated on $3 \%$ agarose gels and visualized by ethidium bromide staining. The resulting gels were scanned with a Pdi scanner (model 420oe, Pdi; Huntington Station, NY) and the densitometry analyzed with the ImageJ 1.32 program. We also chose the housekeeping gene $18 \mathrm{~S}$ rRNA as an endogenous standard. The RT-PCR product from $18 \mathrm{~S}$ rRNA-specific primers (Ambion) produced a 488-base pair fragment.

\subsection{Membrane Protein Preparation and Western Blot Analysis}

Both transfected and non-transfected VSMCs were washed twice with ice-cold phosphatebuffered saline, then dislodged and homogenized in ice-cold Tris-HCl buffer $(50 \mathrm{mmol} / \mathrm{L} \mathrm{Tris,}$ $5 \mathrm{mmol} / \mathrm{L} \mathrm{EDTA}, 150 \mathrm{mmol} / \mathrm{L} \mathrm{NaCl}$ ) and centrifuged at $51500 \mathrm{~g}$ for 30 minutes at $4^{\circ} \mathrm{C}$. The pellet was resuspended in the same buffer and homogenized again. The protein concentration was determined by the Bio-Rad DC protein assay. Samples (in equal protein concentration) were mixed with $3 \times$ loading buffer $(0.2 \mathrm{M}$ Tris-Cl PH $6.8,6 \%$ SDS, $30 \%$ glycerol, $2 \%$ DTT, $0.03 \%$ bromophenol blue) and heated at $95^{\circ} \mathrm{C}$ for 5 minutes. Gel electrophoresis was performed at $5 \%$ stacking, $10 \%$ separating SDS-polyacrylamide gels. Proteins were subsequently transferred to a pure nitrocellulose membrane (Bio-Rad, Hercules, CA) for $1 \mathrm{hr}$ at $90 \mathrm{~V}$. Following this, the blot membrane was incubated for $1 \mathrm{hr}$ in blocking buffer (PBS containing $5 \%$ dry non-fat milk and $0.1 \%$ Tween-20). After washing the membrane was incubated overnight at $4{ }^{\circ} \mathrm{C}$ with polyclonal anti- $\alpha_{1 D^{-}}$AR (Santa Cruz Biotechnology, Santa Cruz, California) or anti- $\alpha_{2 \mathrm{~A}}$-AR (Affinity Bioreagents, Golden, CO), or $\beta$-actin (Sigma-Aldrich, Milwaukee, WI) antibody. The antibody solution was removed, and the membranes were washed 3 times with PBS that contained $0.1 \%$ Tween-20. Incubation with horseradish peroxidase-conjugated donkey anti-goat immunoglobulin $\mathrm{G}(\mathrm{IgG})$ secondary antibody (Santa Cruz Biotechnology) at 1:5,000 dilution was carried out for $45 \mathrm{~min}$ at room temperature. 
Chemiluminescence was detected immediately using the ECL Western Blotting Detection Kit (Amersham Bioscience, Buckinghamshire, UK). The quantification of $\alpha_{1 D^{-}} \mathrm{AR}, \alpha_{2 \mathrm{~A}}-\mathrm{AR}$ and $\beta$-actin expression was determined by densitometry scanning followed by computer analysis using the Image J 1.32 program.

\subsection{Statistical Analysis}

All data are expressed as means \pm SD. The statistical analyses were carried out with SAS 8.1 (SAS Institute, Inc, Cary, NC). We used the General Linear Models (GLM) procedure in SAS to compare mean differences across groups, with Duncan adjustment. The control group was set as reference. A P $<0.05$ level of significance was chosen in all of our analyses.

\section{Results}

\subsection{Effects of $\alpha_{1 D}-A R$ siRNA transfection on AR protein levels}

After preliminary transfections with $\alpha_{1 \mathrm{D}}$-AR/Block-it plasmid containing the 4 different target sequences, we chose the one located in 3'UTR (5'-AAACTACTTAGTCAACTCCTA-3') because it produced the maximal inhibition in protein level. Therefore, we used this sequence to make the $\alpha_{1 \mathrm{D}} \mathrm{AR} / \mathrm{pSEC}$ expression plasmid for all subsequent experiments. In nontransfection groups, at either mRNA or protein level, gene expressions remained the same at $24 \mathrm{~h}, 48 \mathrm{~h}$ and $72 \mathrm{~h}$. Therefore, we present one value of non-transfected control for comparison with the transfected groups.

The successful post-transcriptional silencing of the $\alpha_{1 D^{-}} \mathrm{AR}$ gene by the selected siRNA nucleotide sequence was demonstrated by the highly significant decrease in the level of $\alpha_{1 D^{-}}$ AR protein generation. Figure 1 shows the time-dependent decrease of $\alpha_{1 D^{-}}$AR protein levels in VSMCs evaluated by Western blot analysis at $24 \mathrm{~h}, 48 \mathrm{~h}$ and $72 \mathrm{~h}$ after transfection. Compared to the non-transfected VSMCs, the $\alpha_{1 \mathrm{D}}$-AR protein levels in siRNA-transfected cells at these time points were decreased by 55\% ( $\mathrm{p}<0.07), 69 \%(\mathrm{p}<0.03)$ and $75 \%(\mathrm{p}<$ 0.01 ), respectively. In parallel, in the siRNA transfected cells there was a significant increase in $\alpha_{2 \mathrm{~A}}$-AR protein level that peaked at $48 \mathrm{~h}$ and tended to return to baseline thereafter (Figure 2).

\subsection{Effects of $\alpha_{1 D}-A R$ siRNA transfection on AR gene expression}

Using quantitative RT-PCR we evaluated the changes in AR-gene expression at $24 \mathrm{~h}, 48 \mathrm{~h}$ and $72 \mathrm{~h}$ after transfection of VSMCs by the $\alpha_{1 \mathrm{D}}$-AR specific siRNA. Figure 3 shows the progressive increase in $\alpha_{1 \mathrm{D}}$-AR gene expression, which tended to rise at $48 \mathrm{~h}$ and increased significantly by $61 \%$ at $72 \mathrm{~h}(\mathrm{p}<0.05)$, in parallel to the progressive decline in generation of its protein. At the same time, there were changes in gene expression of other related ARs. Table 2 shows that the post-transcriptional silencing of the $\alpha_{1 D^{-}}$AR gene was associated with a steep decrease in expression of the $\alpha_{1 \mathrm{~A}}$-AR gene $(\mathrm{p}<0.05)$, the $\alpha_{2 \mathrm{~A}}$-AR gene $(\mathrm{p}<0.01)$ and the $\alpha_{2 \mathrm{C}}$-AR gene (although the last did not attain significance), between $24 \mathrm{~h}$ and $48 \mathrm{~h}$, with no further change at $72 \mathrm{~h}$; whereas the $\alpha_{1 \mathrm{~B}}-\mathrm{AR}$ gene expression remained unchanged (The $\alpha_{2 B}$-AR gene was undetectable in aortic VSMC in accordance with our previous finding (Handy et al., 1998)). The expression of the $\beta_{3}$-AR gene was also significantly decreased at $48 \mathrm{~h}$ ( $\mathrm{p}<$ $0.05)$ and $72 \mathrm{~h}(\mathrm{p}<0.01)$, whereas the $\beta_{1}$-AR gene tended also to decrease its expression and the $\beta_{2}$-AR gene remained unchanged.

\section{Discussion}

Gene therapy has been recently proposed as a new approach for the treatment of hypertension (Phillips, 2001), aiming at altering the levels or function of various vasoactive systems. Approaches have included the delivery of extra copies of candidate genes, whose products 
contribute to vasodilation, and the inhibition of expression of genes, whose products contribute to vasoconstriction. The latter approach has consisted mostly of antisense oligodeoxynucleotides targeting a specific gene sequence, in order to suppress the gene's expression. The antisense sequence is delivered either naked or attached to a plasmid vector or an adeno-associated viral vector, in order to prolong its action. In recent years, we have explored all three methods in order to reverse salt-induced hypertension by targeting the $\alpha_{2 B^{-}}$ AR gene (Kintsurashvili et al., 2001; Kintsurashvili et al., 2003; Shenouda et al., 2006). The current experiments were designed to explore in vitro an alternative method of inhibiting gene expression of an $\alpha$-AR subtype, namely, that of post-transcriptional silencing by RNAi, and we chose as target the VSMC $\alpha_{1 D^{-}}$AR. Although different $\alpha_{1}$-AR subtypes have been reported to predominate in different arteries of various animal species, the $\alpha_{1 \mathrm{D}} \mathrm{AR}$ is predominant in the aortic wall and has been shown to be mostly responsible for catecholamine-induced systemic vasoconstriction. We selected the post-transcriptional silencing of the gene by siRNA, which requires only a few molecules of double-stranded RNA (dsRNA) to almost completely abolish the encoded product of a gene homologous to the dsRNA. We demonstrated that transfection of VSMCs with the selected $\alpha_{1 \mathrm{D}} /$ siRNA nucleotide sequence, progressively decreased the production of $\alpha_{1 \mathrm{D}}$-AR protein (assessed by Western blot) up to $75 \%$ over the next three days. In parallel, there was a gradual increase of up to $61 \%$ in the degree of expression of the $\alpha_{1 \mathrm{D}}$-AR gene (as assessed by RT-PCR), probably reflecting an unsuccessful effort to counteract the loss of receptor protein resulting from post-transcriptional silencing. Of particular interest, however, was the concurrent increase in $\alpha_{2 \mathrm{~A}}$-AR protein level within these VSMCs, with a subsequent decrease in the expression of that gene. This appears to be a compensatory reaction aiming at preserving to a large extent the contractile capacity of the VSMCs in response to adrenergic stimuli, since the postsynaptic $\alpha_{2 \mathrm{~A}}$-AR is also a major contributor to catecholamine-induced vasoconstriction (Duka et al., 2000).

Several other AR genes were also found to exhibit diminished expression over the next $72 \mathrm{~h}$, most pronounced in the $\alpha_{1 \mathrm{~A}}, \alpha_{2 \mathrm{~A}}$ and $\beta_{3}$-AR genes. All AR subtypes belong to the same G protein-coupled receptor superfamily of membrane proteins (Bylund, 1992; Lefkowitz and Caron, 1988) with overlapping functions in response to various ligands. Furthermore, they are encoded by genes with similar features, suggesting that all may have evolved from a single ancestral gene, which would explain conservation of particular sequences and spacing between key functional amino acids. Therefore, it should not be surprising that cross-talk exists among these genes (Deng et al., 1998), so that suppressing the activity of one would lead to compensatory reactions from others, whose activation elicits similar responses (Daly et al., 2002; Devic et al., 2001; Hutchinson et al., 2001; Trendelenburg et al., 2001). In selecting the target sequence for $\alpha_{1 \mathrm{D}}$-AR RNAi, we ensured that there was no homologous sequence with other off-target genes. Accordingly, any changes in related other AR genes should be attributable to cross-talk rather than to inadvertent interference with those genes' RNA. The specificity of siRNA-mediated RNAi for the $\alpha_{1 D^{-}} \mathrm{AR}$ was further ascertained by the use of a GAPDH siRNA vector as a positive control; by demonstrating that the 21-nucleotide sequence selected uniquely against the GAPDH mRNA had no influence on the $\alpha_{1 \mathrm{D}}$-AR gene expression or protein production, we proved that changes in expression of various AR genes following transfection of $\alpha_{1 D^{-}}$AR siRNA were not unexpected non-specific reactions, but rather the results of cross-talk among genes of receptors with overlapping structural and functional characteristics (Ruffolo et al., 1991).

Compensatory alterations have been described before in related receptors when one receptor is blocked or its gene is deleted: examples are upregulation of $\alpha$-AR or $\beta$-AR subtypes in gene knockout mice with deletion of other $\alpha$ or $\beta$-AR subtypes (Daly et al., 2002; Devic et al., 2001; Hutchinson et al., 2001; Rohrer et al., 1999; Trendelenburg et al., 2001). In fact, when a normal AR-receptor population is genetically suppressed, another AR-subtype can replace it with a similar cellular distribution. Thus, in $\alpha_{1 \mathrm{~B}}$-AR knockout mice, hepatic function of 
$\alpha_{1 \mathrm{~B}}$-ARs is assumed by $\alpha_{1 \mathrm{~A}}$-AR (Deighan et al., 2004); in $\alpha_{1 \mathrm{D}}$-AR knockout mice, the expression of $\alpha_{1 \mathrm{~A}^{-}}$and $\alpha_{1 \mathrm{~B}}$-AR tended to increase in brain tissues compared to wildtype mice (Tanove et al., 2002), and so did the mesenteric artery expression of $\alpha_{1 \mathrm{~A}^{-}} \mathrm{AR}$ in double $\alpha_{1 \mathrm{D}^{-}}$ and $\alpha_{1 B}$-AR knockouts (Hosoda et al., 2005). This is by no means unique to ARs: in a series of experiments investigating the properties of bradykinin receptors, we also demonstrated that pharmacologic blockade or genetic engineering to eliminate one type of bradykinin receptor leads to upregulation of the other, which compensates for many of the affected receptor's functions (Duka et al., 2001; Duka et al., 2003).

\section{Conclusions}

In summary, in these experiments we employed the method of RNAi via siRNA for posttranscriptional silencing of the $\alpha_{1 D^{-}}$AR gene in rat VSMCs. We demonstrated that the approach can profoundly suppress the production of the targeted protein despite subsequent significant reactive upregulation of the target gene, and that such interference leads to cross-talk among related AR-genes with significant concurrent alterations in their expression patterns. Further experiments in vivo are needed to explore whether this approach to gene treatment would yield the hemodynamic results expected from blockade of the selected gene, or whether compensatory changes from genes of receptors with overlapping structure/function characteristics might minimize the anticipated effects. The potential therapeutic implications of this treatment are of great interest, since pharmacologic blockade of $\alpha_{1}$-ARs is widely used as adjunct treatment for hypertension, as well as urinary bladder and sphincter disorders.

\section{Acknowledgements}

This study was partially supported by NIH Grant R01 HL 65311.

\section{References}

Bylund DB. Subtypes of $\alpha 1$ - and $\alpha$ 2-adrenergic receptors. Faseb J 1992;6:832-839. [PubMed: 1346768]

Daly CJ, Deighan C, McGee A, Mennie D, Ali Z, McBride M, McGrath JC. A knockout approach indicates a minor vasoconstrictor role for vascular $\alpha 1 \mathrm{~B}$-adrenoceptors in mouse. Physiol Genomics 2002;9:85-91. [PubMed: 12006674]

Deighan C, Woollhead AM, Colston JF, McGrath JC. Hepatocytes from $\alpha 1$ B-adrenoceptor knockout mice reveal compensatory adrenoceptor subtype substitution. Br J Pharmacol 2004;142:1031-1037. [PubMed: 15210583]

Deng XF, Sculptoreanu A, Mulay S, Peri KG, Li JF, Zheng WH, Chemtob S, Varma DR. Crosstalk between $\alpha-1 \mathrm{~A}$ and $\alpha-1 \mathrm{~B}$ adrenoceptors in neonatal rat myocardium: implications in cardiac hypertrophy. J Pharmacol Exp Ther 1998;286:489-496. [PubMed: 9655894]

Devic E, Xiang Y, Gould D, Kobilka B. Beta-adrenergic receptor subtype-specific signaling in cardiac myocytes from $\beta 1$ and $\beta 2$ adrenoceptor knockout mice. Mol Pharmacol 2001;60:577-583. [PubMed: 11502890]

Duka I, Duka A, Kintsurashvili E, Johns C, Gavras I, Gavras H. Mechanisms mediating the vasoactive effects of the $B_{1}$ receptors of bradykinin. Hypertension 2003;42:1021-1025. [PubMed: 14557281]

Duka I, Gavras I, Johns C, Handy DE, Gavras H. Role of the postsynaptic $\alpha_{2}$-adrenergic receptor subtypes in catecholamine-induced vasoconstriction. Gen Pharmacol The Vascular System 2000;34:101-106.

Duka I, Kintsurashvili E, Gavras I, Johns C, Bresnahan M, Gavras H. Vasoactive Potential of the B Bradykinin Receptor in Normotension and Hypertension. Circ Res 2001;88:275-281. [PubMed: 11179194]

Elbashir SM, Harborth J, Lendeckel W, Yalcin A, Weber K, Tuschl T. Duplexes of 21-nucleotide RNAs mediate RNA interference in cultured mammalian cells. Nature 2001;411:494-498. [PubMed: 11373684]

Endoh M, Hiramoto T, Ishihata A, Takanashi M, Inui J. Myocardial $\alpha 1$-adrenoceptors mediate positive inotropic effect and changes in phosphatidylinositol metabolism. Species differences in receptor 
distribution and the intracellular coupling process in mammalian ventricular myocardium. Circ Res 1991;68:1179-1190. [PubMed: 1850328]

Gavras, H.; Handy, D.; Gavras, I. Alpha-adrenergic Receptors in Hypertension. In: Laragh, JH.; Brenner, BM., editors. Hypertension: Pathophysiology, Diagnosis, and Management. Raven; New York: 1995. p. 853-861.

Gavras I, Manolis AJ, Gavras H. The $\alpha 2$-adrenergic receptors in hypertension and heart failure: experimental and clinical studies. J Hypertens 2001;19:2115-2124. [PubMed: 11725152]

Gisbert R, Noguera MA, Ivorra MD, D'Ocon P. Functional evidence of a constitutively active population of $\alpha 1 \mathrm{D}$-adrenoceptors in rat aorta. J Pharmacol Exp Ther 2000;295:810-817. [PubMed: 11046122]

Gitlin L, Karelsky S, Andino R. Short interfering RNA confers intracellular antiviral immunity in human cells. Nature 2002;418:430-434. [PubMed: 12087357]

Handy DE, Johns C, Bresnahan MR, Tavares A, Bursztyn M, Gavras H. Expression of $\alpha_{2}$-adrenergic receptors in normal and atherosclerotic rabbit aorta. Hypertension 1998;32:311-317. [PubMed: 9719060]

Hosoda C, Tanoue A, Shibano M, Tanaka Y, Hiroyama M, Koshimizu TA, Cotecchia S, Kitamura T, Tsujimoto G, Koike K. Correlation between vasoconstrictor roles and mRNA expression of alpha1adrenoceptor subtypes in blood vessels of genetically engineered mice. Br J Pharmacol 2005;146:456-466. [PubMed: 16113694]

Hrometz SL, Edelmann SE, McCune DF, Olges JR, Hadley RW, Perez DM, Piascik MT. Expression of multiple alpha1-adrenoceptors on vascular smooth muscle: correlation with the regulation of contraction. J Pharmacol Exp Ther 1999;290:452-463. [PubMed: 10381812]

Hutchinson DS, Evans BA, Summers RJ. $\beta 1$-Adrenoceptors compensate for $\beta 3$-adrenoceptors in ileum from $\beta 3$-adrenoceptor knockout mice. Br J Pharmacol 2001;132:433-442. [PubMed: 11159692]

Ikeda U, Tsuruya Y, Yaginuma T. $\alpha 1$-adrenergic stimulation is coupled to cardiac myocyte hypertrophy. Am J Physiol 1991;260:H953-956. [PubMed: 1848051]

Jeffries WB, Yang E, Pettinger WA. Renal $\alpha 1$-adrenergic receptor response coupling in spontaneously hypertensive rats. Hypertension 1988;12:80-88. [PubMed: 2840396]

Kenny BA, Chalmers DH, Philpott PC, Naylor AM. Characterization of an alpha 1D-adrenoceptor mediating the contractile response of rat aorta to noradrenaline. Br J Pharmacol 1995;115:981-986. [PubMed: 7582530]

Kintsurashvili E, Gavras I, Johns C, Gavras H. Effects of Antisense oligodeoxynucleotide targeting of the $\alpha_{2 \mathrm{~B}}$-adrenergic receptor messenger RNA in the central nervous system. Hypertension 2001;38:1075-1080. [PubMed: 11711500]

Kintsurashvili E, Johns C, Ignjacev I, Gavras I, Gavras H. Central $\alpha_{2 B}$-adrenergic receptor antisense in plasmid vector prolongs reversal of salt-dependent hypertension. J Hypertens 2003;21:961-967. [PubMed: 12714871]

Kurz T, Yamada KA, DaTorre SD, Corr P. Alpha1-adrenergic system and arrhythmias in ischaemic heart disease. Eur Heart J 1991;12(Suppl F):88-98. [PubMed: 1666558]

Lefkowitz RJ, Caron MG. Adrenergic receptors. Models for the study of receptors coupled to guanine nucleotide regulatory proteins. J Biol Chem 1988;263:4993-4996. [PubMed: 3128532]

Makaritsis KP, Johns C, Gavras I, Gavras H. Role of $\alpha_{2}$-adrenergic receptor subtypes in the acute hypertensive response to hypertonic saline infusion in anephric mice. Hypertension 2000;35:609613. [PubMed: 10679505]

McManus MT, Sharp PA. Gene silencing in mammals by small interfering RNAs. Nat Rev Genet 2002;3:737-747. [PubMed: 12360232]

Phillips MI. Gene therapy for hypertension: the preclinical data. Hypertension 2001;38:543-548. [PubMed: 11566928]

Piascik MT, Guarino RD, Smith MS, Soltis EE, Saussy DL Jr, Perez DM. The specific contribution of the novel $\alpha-1 \mathrm{D}$ adrenoceptor to the contraction of vascular smooth muscle. J Pharmacol Exp Ther 1995;275:1583-1589. [PubMed: 8531132]

Rohrer DK, Chruscinski A, Schauble EH, Bernstein D, Kobilka BK. Cardiovascular and metabolic alterations in mice lacking both $\beta 1$ - and $\beta 2$-adrenergic receptors. J Biol Chem 1999;274:1670116708. [PubMed: 10358009] 
Ruffolo RR Jr, Nichols AJ, Oriowo MA. Interaction of vascular $\alpha$-1 adrenoceptors with multiple signal transduction pathways. Blood Vessels 1991;28:122-128. [PubMed: 1848121]

Ross R. The smooth muscle cell. II Growth of smooth muscle in culture and formation of elastic fibers. J Cell Biol 1971;50:172-186. [PubMed: 4327464]

Shenouda SM, Johns C, Kintsurashvili E, Gavras I, Gavras H. Long-Term Inhibition of the Central $\alpha 2 B-$ Adrenergic Receptor Gene via Recombinant Adeno-associated Virus-Delivered Antisense DNA in Hypertensive Rats. Am J Hypertens. 2006(in press)

Tanoue A, Nasa Y, Koshimizu T, Shinoura H, Oshikawa S, Kawai T, Sunada S, Takeo S, Tsujimoto G. The $\alpha 1 \mathrm{D}$-adrenergic receptor directly regulates arterial blood pressure via vasoconstriction. J Clin Invest 2002;109:765-75. [PubMed: 11901185]

Trendelenburg AU, Norenberg W, Hein L, Meyer A, Starke K. Alpha2-adrenoceptor-mediated inhibition of cultured sympathetic neurons: changes in alpha2A/D-adrenoceptor-deficient mice. Naunyn Schmiedebergs Arch Pharmacol 2001;363:110-119. [PubMed: 11191829]

Villalobos-Molina R, Ibarra M. Vascular $\alpha 1 \mathrm{D}$-adrenoceptors: are they related to hypertension? Arch Med Res 1999;30:347-352. [PubMed: 10596451]

Young MA, Vatner DE, Knight DR, Graham RM, Homcy CJ, Vatner SF. Alpha-adrenergic vasoconstriction and receptor subtypes in large coronary arteries of calves. Am J Physiol 1988;255:H1452-1459. [PubMed: 2904772] 


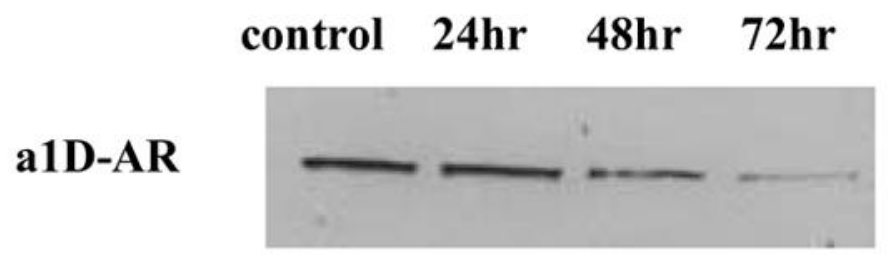

B- actin

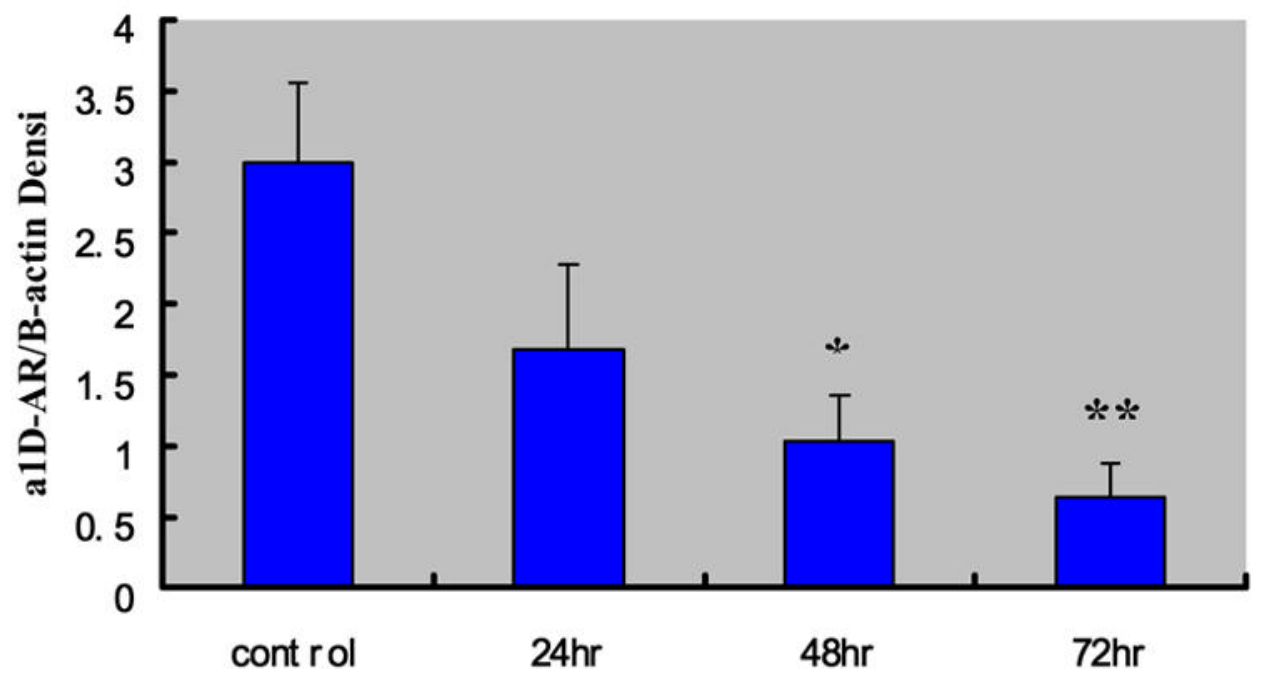

Figure 1.

Effects of siRNA on the protein level of $\alpha_{1 \mathrm{D}}-\mathrm{AR}$ at $24 \mathrm{hrs}, 48 \mathrm{hrs}$ and $72 \mathrm{hrs}$ after transfection (mean \pm standard deviation from six independent experiments) The densitometry of different groups was adjusted according to that of $\beta$-actin. $* \mathrm{P}<0.05$; $* * \mathrm{P}<0.01$ compared to the non transfection control group. 


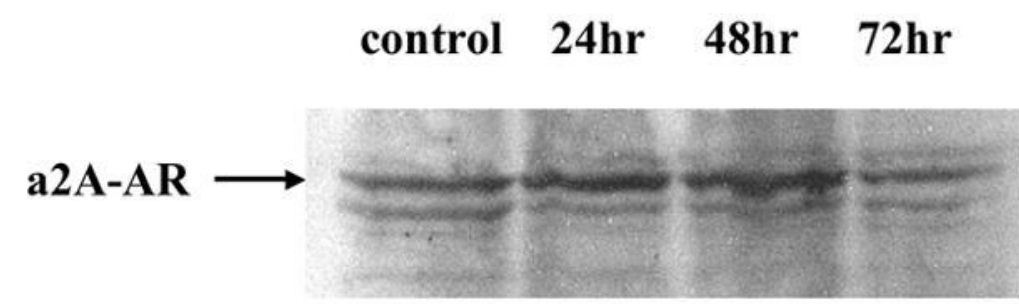

\section{B- actin}

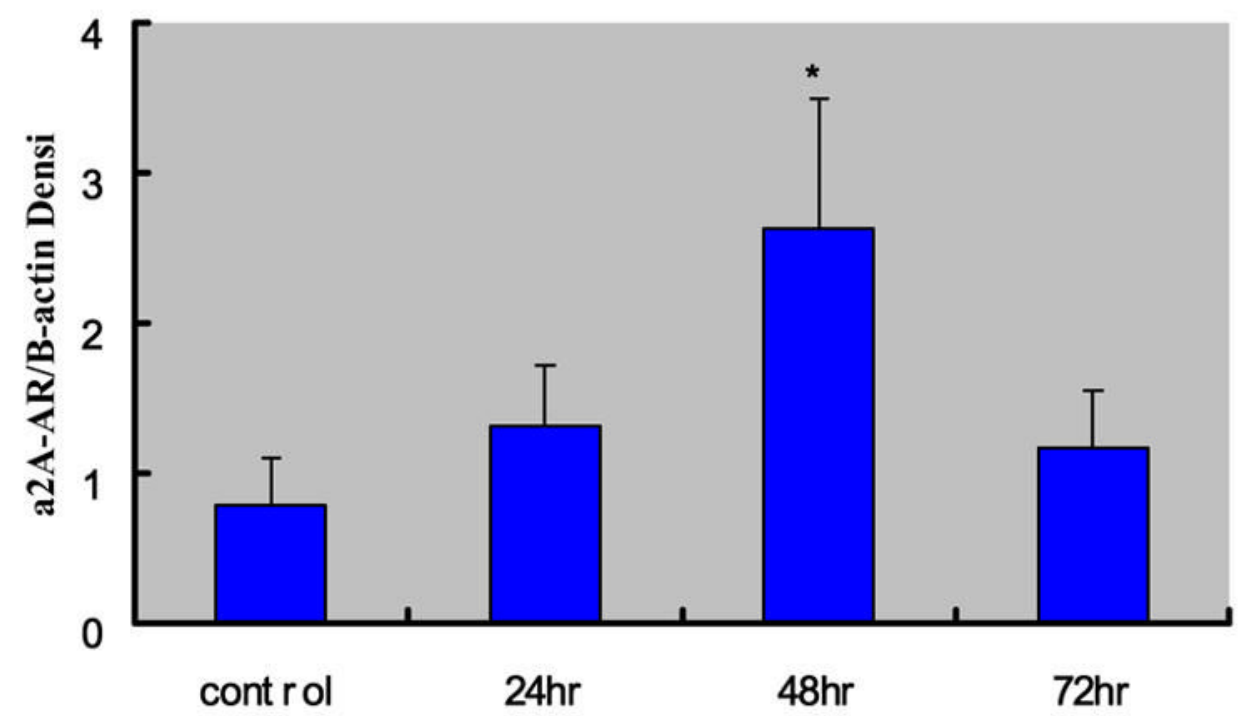

Figure 2.

Effects of $\alpha_{1 D^{-}} \mathrm{AR} / \mathrm{siRNA}$ on the protein expression level of $\alpha_{2 \mathrm{~A}}$-AR at $24 \mathrm{hrs}, 48 \mathrm{hrs}$ and 72 hrs after transfection (mean \pm standard deviation from six independent experiments). The densitometry of different groups was adjusted according to that of $\beta$-actin. ${ }^{*} \mathrm{P}<0.05$ compared to the control group. 

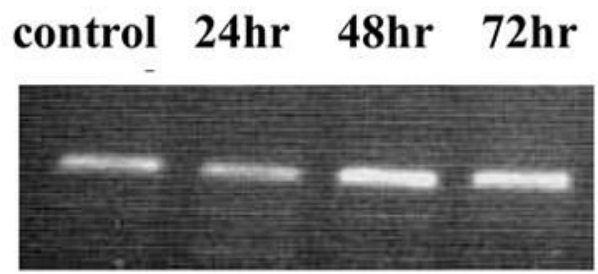

\section{a1D-AR}

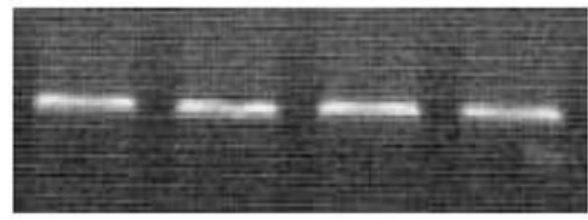

$18 S$

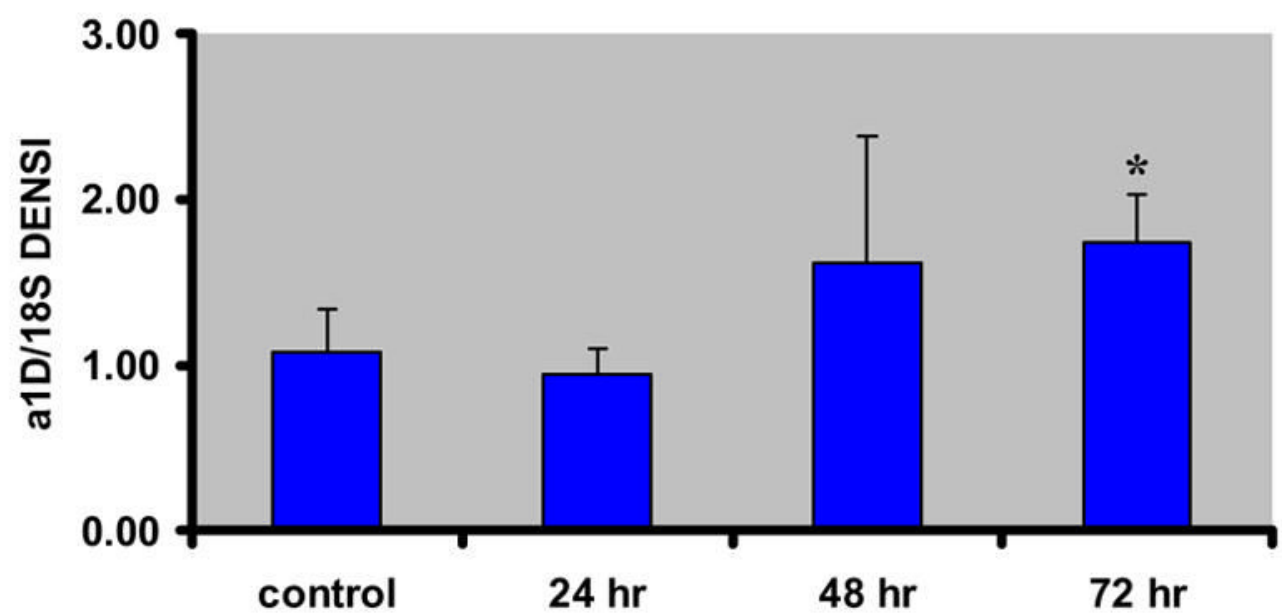

Figure 3.

Effects of siRNA on the level of mRNA expression of $\alpha_{1 \mathrm{D}}$-AR gene at $24 \mathrm{hrs}, 48 \mathrm{hrs}$ and 72 hrs after transfection (mean \pm standard deviation from six independent experiments). The densitometry of different groups was adjusted according to that of $18 \mathrm{~S}$. *P $<0.05$ compared to the control group. 
Table 1

The forward and reverse primers and the length of PCR product in each AR-subtype for RT-PCR

\begin{tabular}{|c|c|c|}
\hline AR-Subtype & Sequence & Fragment Length \\
\hline$\alpha 1 \mathrm{~A}$ & $\begin{array}{l}\text { F 5'-GAATGTCCTGCGAATCCAGT-3' } \\
\text { R 5'-GATTGGTCCTTGGCACTGT-3' }\end{array}$ & 237 \\
\hline$\alpha 1 \mathrm{~B}$ & $\begin{array}{l}\text { F 5'-AACCTTGGGCATTGTAGTCG-3', } \\
\text { R 5'ACCCAAGGATACGCATGAAG-3', }\end{array}$ & 212 \\
\hline$\alpha 1 \mathrm{D}$ & $\begin{array}{l}\text { F 5'-AGCCTCTGCACCATCTCTGT-3' } \\
\text { R 5'-AAGGAGCACACGGAAGAGAA-3' }\end{array}$ & 233 \\
\hline$\alpha 2 \mathrm{~A}$ & $\begin{array}{l}\text { F 5'-GGTAAGGTGTGGTGCGAGAT-3' } \\
\text { R 5'-CAGCGCCCTTCTTCTCTATG-3' }\end{array}$ & 229 \\
\hline$\alpha 2 \mathrm{C}$ & $\begin{array}{l}\text { F 5'-TACTGTGCTGGTTCCCCTTC-3' } \\
\text { R 5'-CAGAGGCCCAGTTGTCTCTC-3' }\end{array}$ & 245 \\
\hline$\beta 1$ & $\begin{array}{l}\text { F 5'-CATCACGCTGCCCTTTCGC-3', } \\
\text { R 5'-CGGTTGGTGACGAAATCGC-3' }\end{array}$ & 256 \\
\hline$\beta 2$ & $\begin{array}{l}\text { F 5'-AAGTTCGAGCGACTACAAACCGT-3', } \\
\text { R 5'-TGAAGAAGTCACAGCAAGTCTCC-3' }\end{array}$ & 279 \\
\hline$\beta 3$ & $\begin{array}{l}\text { F 5'-ACAGACCATAACCAACGTGTTCG-3', } \\
\text { R 5'-GAACACTCGAGCATAGACGAAGA-3' }\end{array}$ & 284 \\
\hline
\end{tabular}


Table 2

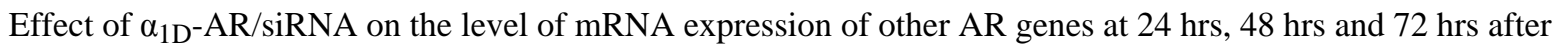
transfection assessed by densitometry

\begin{tabular}{lllll}
\hline & Control & 24h & 48h & 72h \\
\hline$\alpha_{1 \mathrm{~A}}$ & $1.72 \pm 0.64$ & $1.83 \pm 0.16$ & $0.88 \pm 0.14$ & $0.79 \pm 0.18^{*}$ \\
$\alpha_{1 \mathrm{~B}}$ & $1.69 \pm 0.26$ & $1.32 \pm 0.20$ & $1.30 \pm 0.21$ & $1.39 \pm 0.24$ \\
$\alpha_{2 \mathrm{~A}}$ & $1.99 \pm 0.25$ & $1.90 \pm 0.05$ & $1.06 \pm 0.10^{* *}$ & $0.79 \pm 0.12^{* *}$ \\
$\alpha_{2 \mathrm{C}}$ & $1.24 \pm 0.71$ & $1.38 \pm 0.56$ & $0.62 \pm 0.27$ & $0.59 \pm 0.47$ \\
$\beta_{1}$ & $0.71 \pm 0.55$ & $1.27 \pm 0.93$ & $0.95 \pm 0.36$ & $0.44 \pm 0.14$ \\
$\beta_{2}$ & $1.48 \pm 1.06$ & $1.56 \pm 0.99$ & $1.43 \pm 0.82$ & $0.82 \pm 0.22$ \\
$\beta_{3}$ & $0.95 \pm 0.18$ & $0.97 \pm 0.48$ & $0.30 \pm 0.04^{*}$ & $0.16 \pm 0.94^{* *}$ \\
\hline
\end{tabular}

Each value is the mean \pm SD of six independent experiments. The densitometry of different groups was adjusted according to that of $18 \mathrm{~S}$.

P $\mathrm{P}<0.05$

** $\mathrm{P}<0.01$ as compared to the control group. 